\title{
White Australia has a Blackie Blackie Brown history
}

\author{
Kezia Aria \\ University of Technology Sydney, Faculty of Arts and Social Sciences, PO Box 123, Ultimo \\ NSW 2007, Australia. kezia.d.aria@student.uts.edu.au
}

When people talk about "the history of Australia" they mean the history of white people who have lived in Australia. (Reynolds 1999)

The gatekeepers for institutions of fine arts, classical music and theatre in Australia are traditionally white, upper middle-class people. Nakkiah Lui's existence and success as an Indigenous playwright is a radical disturbance in this bubble of society as, by nature, stories and storytellers that challenge cultural hegemony will always be political, and Blak artists entering theatre demonstrate a fusion and adaptation of Indigenous oral traditions into Australia's highbrow society. Aboriginal playwrights and performances have a complex history in terms of audience reception as they often deal with difficult and confronting topics that 'regular' theatre audiences may not engage with (Grehan 2010). Not only do they have the burden of representing 'all' Aboriginal people, but the stories they share are often those whose voices were historically silenced, erased or dismissed (Morris 1992).

However, Lui continues to persevere, shocking and entertaining her audiences through humour and satire in the spirit of Blak comedy. She delivers fresh narratives that confront serious social and political issues such as white supremacy and colonisation through an Aboriginal perspective, and these themes are most evidently explored in her 2018 play, Blackie Blackie Brown: The Traditional Owner of Death which is explicitly not about reconciliation with or the forgiveness of white settlers.

The play follows archaeologist Dr Jacqueline 'Blackie' Black who discovers her great-greatgrandmother's skull during a dig for a suspicious company who wanted to build on the land. The story effortlessly switches between comedy to a serious and melancholic tone when the skull evokes her ancestor's spirit who jarringly details the trauma of violent massacre and rape her children, her mob and herself had experienced by four white male assailants. Her great-great-grandmother pleads to Blackie to take revenge on all 400 descendants of these men through the means of assassination, gifting her with superpowers and birthing the 
superhero alter ego 'Blackie Blackie Brown'. However, as the story unfolds the protagonist learns that an eye for an eye makes the world go blind.

This review's primary focus is Lui bringing a truer more emotional account of Australia's colonial and violent history to the forefront of the Australian public's consciousness, through the media and entertainment they consume. Despite momentous gestures and national apologies such as Prime Minister Kevin Rudd's apology speech to the Stolen Generations in 2008, where no effective changes were made to Indigenous living conditions, and the general population believing they are of a progressive society — whether they actually are or aren'tthere is a large gap between Indigenous and non-Indigenous Australians. With the lack of social or cultural exchanges made between the groups being at the centre of the issue (Grehan 2010), mainstream entertainment is an effective method in bridging these two together.

Between traditional and revisionist 'black arm-band' historians arguing over true objectivity and allegations made of the other's version of history being prejudiced by social and political agendas, it is at this moment that the role of art and literature-including in the form of theatre-becomes key. Storytelling eludes the critiques of bias because objective fact is not a requirement, and it presents stories which can influence how Australia's history is framed, understood and sympathised with (Radhika 2010).

Theatre as a method of framing Australia's violent and confronting history is significant because although it does not claim objectivity nor request the audience's trust in the means that traditional written history does, it has the ability to very openly question the supposedly impartial history we were taught by white institutions. And contrary to popular belief, the majority of Australia is still very afraid of its own violent and confronting past (Curthoys 2008). So, theatre defies this by inserting historically-based stories within the framework of art (Radhika 2010), specifically theatrical drama.

Indigenous-led theatre productions have the potential to establish a sense of compassionate 'remembrance' and understanding within theatre-going audiences that can frame how historical events are perceived. The performances that share these difficult and traumatic histories challenge spectators and critics to broaden how theatre is interpreted, so that when plays of Indigenous perspectives or by Indigenous playwrights are consumed and engaged with, it is done in the knowledge that it is culturally, socially and politically significant, especially within the current Australian context (Grehan 2010). Aboriginal methods in recording history has, since the beginning, been doubted and continuously questioned as history is primarily written, by tradition of white historians and academics - and if not, it is drawn, documented, photographed or recorded 'on paper', or something tangible; that is, to white standards.

On the other hand, Aboriginal history was and is predominantly recorded through oral storytelling, with the other method being traditional Aboriginal art (Radhika 2010). Therefore, Aboriginal people and their ties with art, whether it be in the form of dancing, 
paintings or literally theatre, to record and recite their history are a continued legacy that is only a long held cultural tradition.

Through confronting and comedic storytelling, Indigenous actor, writer, comedian and playwright, Nakkiah Lui, has on more than one occasion effectively evoked emotion and understanding among diverse audiences, bridging the social and cultural gap between Indigenous and non-Indigenous people. Presenting stories interwoven with historical accounts and socio-political debates within a sphere of those who majority hold settler privilege, she has been capable of providing Australians with the necessary broadened and informed frame of mind to interpret and critically analyse the history that the majority of the population are exposed to. She disrupts the cultural hegemony and shifts attention to past and current Indigenous-related atrocities and issues by creating fictional characters such as Blackie Blackie Brown and her great-great-grandmother that are very much real as they have dealt or are dealing with real-life issues.

\section{References}

Curthoys, A. 2008, 'WEH Stanner and the historians', in M. Hinkson \& J. Beckett (eds), An Appreciation of Difference: WEH Stanner and Aboriginal Australia, 1 stedn, Aboriginal Studies Press, Canberra, ACT, pp. 233-250.

Grehan, H. 2010, 'Aboriginal performance: politics, empathy and the question of reciprocity’, Australasian Drama Studies, vol. 56, pp. 38-53.

Morris, B., 1992, 'Frontier colonialism as a Culture of Terror', Journal of Australian Studies, vol. 16 , no. 35 , pp. $72-87$.

Radhika, K. G. Naga, 2010, 'Presenting the Past: Historiography in Aboriginal Theatre of the 80s and 90s', Southerly, vol. 70, no. 3, pp. 144-162.

Reynolds, H. 1999, Why Weren't We Told? A Personal Search for the Truth about Our History, 2ndedition, Penguin Books Australia, Australia. 